\title{
Pengaruh Budaya Sekolah dan Diklat terhadap Kinerja Guru
}

\author{
Muhammad Dahlan $\bowtie 1$, Yasir Arafat ${ }^{2}$, Syaiful Eddy ${ }^{3}$ \\ (1) Sekolah Dasar Negeri 1 Sungai Lilin \\ $(2,3)$ Universitas PGRI Palembang
}

$\square$ Corresponding author [dahlan.jawi@gmail.com]

\begin{abstract}
Abstrak
Penelitian bertujuan untuk mengetahui pengaruh budaya sekolah dan Diklat terhadap kinerja guru sekolah dasar. Data penelitian ini dikumpulkan melalui penyebaran kuesioner kepda responden. Hasil angket dianalisis dengan menggunakan analisis regresi berganda melalui uji t, uji $F$, dan koefisien determinasi. Populasi dalam penelitian ini adalah seluruh guru SD Negeri di Kecamatan Sungai Lilin yang berjumlah 74 orang. Teknik pengambilan sampel yang digunakan adalah purposive sampling. Sampel penelitian adalah 44 orang guru PNS. Hasil penelitian menunjukkan bahwa: 1) ada pengaruh yang signifikan budaya sekolah terhadap kinerja guru di SD Negeri Kecamatan Sungai Lilin; 2) ada pengaruh yang signifikan diklat terhadap kinerja guru di SD Negeri Kecamatan Sungai Lilin; 3) ada pengaruh yang signifikan budaya sekolah dan diklat secara bersama-sama terhadap kinerja guru di SD Negeri Kecamatan Sungai Lilin.
\end{abstract}

Kata Kunci: Budaya Sekolah; Diklat; Kinerja Guru

\begin{abstract}
This study determined the effect of school culture and education and training on the performance of elementary school teachers. The research data was collected by distributing questionnaires to respondents. The results of the questionnaire were analyzed using multiple regression analysis through the $\mathrm{t}$ test, $\mathrm{F}$ test, and the coefficient of determination. The population in this study were all SD Negeri teachers in Sungai Lilin sub-district, totaling 74 people. The sampling technique used was purposive sampling. The research sample was 44 civil servant teachers. The results showed that: 1 ) there is a significant effect of school culture on teacher performance in SD Negeri Sungai Lilin subdistrict; 2) there is a significant effect of education and training on teacher performance in SD Negeri Sungai Lilin subdistrict; 3) there is a significant influence of school culture and education and training together on the performance of teachers in SD Negeri Sungai Lilin District.
\end{abstract}

Keyword: School Culture; Education and Training; Teacher Performance.

\section{PENDAHULUAN}

Secara umum pendidikan merupakan salah satu faktor dan sumber utama bagi kemajuan dan perkembangan negara, sehingga peran pendidikan menduduki posisi sentral dalam peningkatan mutu pembelajaran. Hal ini sejalan dengan pendapat Faturohman (2012) yang mengatakan bahwa pendidikan dikatakan bermutu/berkualitas jika memberikan kebaikan, baik kepada dirinya sendiri/ lembaga pendidikan, kepada orang lain/stakeholder dan orang tua. Education is the most important indicator of a country's progress. Quality education is certainly capable of producing quality human resources too (Asvio et al, 2019). Education as a vital sector in order to build quality human resources, requires a great attention from all parties, because it concerns the quality of the nation (Tobari et al, 2018).

Oleh sebab itu, pendidikan merupakan salah satu penggerak bagi pembangunan dan bekal yang sangat utama dalam mengahadapi perubahan dan perkembangan zaman. Pendidikan atau pengajaran prosesnya diwujudkan dalam proses belajar mengajar. Proses belajar mengajar pada hakekatnya adalah proses komunikasi, yaitu proses penyampaian sebuah pesan dari sumber pesan melalui saluran/fasilitas tertentu ke penerima pesan. Pesan yang akan dikomunikasikan adalah isi ajaran atau materi pembelajaran yang ada dalam kurikulum, sumber pesannya bisa guru dan penerima pesannya adalah siswa (Poerwadarminta, 2015).

Adapun tujuan pendidikan dari suatu lembaga pendidikan pencapaiannya tergantung dari efektifitas pendidikan dan hasilnya atau outputnya ditentukan oleh beberapa faktor misalnya siswa, guru, kurikulum, sarana dan prasarana, dan lingkungan. Dalam kaitannya dengan dunia pendidikan, sarana belajar dapat 
diposisikan sebagai bagian penunjang keberhasilan siswa yang disebut dengan prestasi belajar siswa (Hamalik, 2014).

Buchori (2015) menjelaskan bahwa sekolah merupakan suatu lembaga pendidikan formal yang menyelenggarakan kegiatan proses belajar mengajar sebagai upaya untuk tercapainya tujuan pendidikan. Tinggi rendahnya mutu pendidikan banyak dipengaruhi oleh kualitas proses pembelajaran yang dilakukan oleh guru, karena guru secara langsung memberikan bimbingan dan bantuan kepada siswa dalam upaya mencapai tujuan pendidikan.

Keberhasilan pelaksanaan pembelajaran di sekolah harus dievaluasi secara menyeluruh, antara lain dengan mengevaluasi kualitas proses dan hasil belajar. Secara keseluruhan pemahaman terhadap konsep dasar pembelajaran tidak akan sempurna jika berhenti pada definisi atau proses. Pada dasarnya proses belajar ditandai dengan perubahan tingkah laku secara keseluruhan baik yang menyangkut segi kognitif, afektif, maupun psikomotor. Secara umum hasil belajar siswa dipengaruhi oleh faktor internal yaitu faktor-faktor yang ada dalam diri siswa dan faktor eksternal, yaitu faktor-faktor yang berada di luar diri siswa (Hamalik, 2012).

Dalam kaitannya dengan faktor-faktor yang mempengaruhi hasil belajar diantaranya adalah budaya sekolah. Menurut Sukmadinata (2016) budaya sekolah adalah pola nilai-nilai, prinsip-prinsip, tradisi-tradisi dan kebiasaan-kebiasaan yang terbentuk dalam perjalanan panjang sekolah, dikembangkan sekolah dalam jangka waktu yang lama dan menjadi pegangan serta diyakini oleh seluruh warga sekolah sehingga mendorong munculnya sikap dan perilaku warga sekolah. Budaya sekolah bersifat dinamik, milik seluruh warga sekolah, merupakan hasil perjalanan sekolah, serta merupakan produk dari interaksi berbagai kekuatan yang masuk ke sekolah. Kondisi sekolah yang dinamis merupakan perpaduan seluruh warga sekolah yang memilki latar belakang kehidupan sosial yang berbeda dan saling berinteraksi secara kontinyu, sehingga membentuk sistem nilai yang membudaya dan menjadi milik bersama di sekolah. Budaya yang berintikan tata nilai mempunyai fungsi dalam memberikan kerangka dan landasan yang berupa ide, semangat, gagasan dan cita-cita bagi seluruh warga sekolah.

Budaya sekolah yang kerap disebut dengan iklim kerja yang menggambarkan suasana hubungan kerja antara sesama guru, antara guru dan kepala sekolah, antara guru dan tenaga kependidikan lainnya serta antar dinas di lingkungannya merupakan wujud dari lingkungan yang kondusif. Menurut Zamroni (2011) mengemukakan pentingnya sekolah memiliki budaya atau kultur. Sekolah sebagai suatu organisasi harus memiliki: 1) kemampuan untuk hidup, tumbuh berkembang dan melakukan adaptasi dengan berbagai lingkungan yang ada, dan 2) integrasi internal yang memungkinkan sekolah untuk menghasilkan individu atau kelompok yang memiliki sifat positif. Oleh karenanya suatu organisasi termasuk sekolah harus memiliki pola asumsi-asumsi dasar yang dipegang bersama seluruh warga sekolah.

Lebih lanjut Mulyasa (2012) menjelaskan bahwa budaya sekolah merupakan pola-pola yang mendalam, kepercayaan nilai, upacara, simbol-simbol dan tradisi yang terbentuk dari rangkaian, kebiasaan dan sejarah sekolah, serta cara pandang dalam memecahkan persoalan-persoalan yang ada di sekolah. Budaya sekolah memerlukan fasilitas pembelajaran yang berguna untuk menunjang meningkatnya budaya sekolah yang baik oleh guru dalam hal penyelenggaraan proses belajar mengajar, baik secara langsung maupun tidak langsung dalam suatu lembaga dalam rangka mencapai tujuan pendidikan. Fasilitas pembelajaran adalah salah satu sumber daya yang menjadi tolok ukur mutu sekolah dan perlu peningkatan terus menerus seiring dengan perkembangan ilmu pengetahuan dan teknologi yang cukup canggih.

Peraturan Pemerintah Nomor 32 Tahun 2013 tentang Standar Nasional Pendidikan, Pasal 1 Ayat 9 tentang Standar Sarana dan Prasarana, menegaskan bahwa standar sarana prasarana pembelajaran adalah kriteria mengenai ruang belajar, tempat olahraga, tempat beribadah, perpustakaan, laboratorium, bengkel kerja, tempat bermain, tempat berkreasi dan berekreasi serta sumber belajar lain, yang diperlukan untuk menunjang proses pembelajaran, termasuk penggunaan teknologi informasi dan komunikasi.

Berdasarkan uraian tersebut maka dapat disimpulkan bahwa fasilitas belajar yang merupakan bagian dari budaya sekolah adalah segala sesuatu yang dapat menunjang dan mempermudah kegiatan belajar mengajar. Fasilitas yang dimaksud adalah sarana pendidikan yang ada di sekolah berupa, gedung atau ruang kelas dan perabot serta peralatan pendukung di dalamnya, media pembelajaran, buku atau sumber belajar lainnya. Ketika seorang guru memiliki budaya sekolah yang baik dan didukung oleh fasilitas pembelajaran yang memadai diharapkan akan dapat menunjang keberhasilan dalam melaksanakan tugas dan tanggung jawabnya, khususnya tugas dan tanggung jawabnya sebagai tenaga pengajar.

Hendarman (2018) menjelaskan bahwa keterlibatan kepala sekolah dan guru dalam pengembangan efektivitas pembelajaran di sekolah juga mendorong rasa kepemilikan yang lebih tinggi terhadap sekolahnya yang pada akhirnya mendorong mereka untuk menggunakan sumber daya yang ada dengan seefisien mungkin untuk mencapai hasil yang maksimal. Kepemimpinan kepala sekolah merupakan suatu hal yang menarik untuk dikaji dan dipelajari sebagai upaya mendapatkan sekolah yang baik dan berkualitas.

Guru adalah figur manusia sumber yang menempati posisi dan memegang peran penting dalam pendidikan. Ketika semua orang mempersoalkan masalah dunia pendidikan figur guru mesti terlibat dalam 
agenda pembicaraan terutama yang menyangkut persoalan pendidikan formal di sekolah. Pendidik atau guru merupakan tenaga profesional yang bertugas merencanakan dan melaksanakan proses pembelajaran, menilai hasil pembelajaran, melakukan pembimbingan dan pelatihan, serta melakukan penelitian dan pengabdian kepada masyarakat, terutama bagi pendidik pada perguruan tinggi. Hal tersebut tidak dapat disangkal kerana lembaga pendidikan formal adalah dunia kehidupan guru. Sebagian besar waktu guru ada di sekolah, sisanya ada di rumah dan di masyarakat (Halim, 2014).

Oleh karena itu pemerintah selalu mengadakan peningkatan dan perbaikan dari segi kualitas dan kuantitasnya, seperti kurikulum yang merupakan pedoman guru dalam mengajar. Disamping usaha yang sudah dan sedang dilaksanakan oleh pemerintah terhadap pembaharuan kurikulum itu hendaklah diikutsertakan guru untuk mengembangkan dan meningkatkan ilmu pengetahuannya dalam menjalankan tugas-tugasnya sebagai pendidik, sehingga dapat meningkatkan kinerja guru itu sendiri secara maksimal (Martinis, 2015).

Fakta tersebut mengungkapan betapa guru punya peranan terhadap keberhasilan pendidikan. Guru adalah salah satu tenaga kependidikan yang mempunyai peran sebagai faktor penentu keberhasilan mutu pendidikan di samping tenaga kependidikan lainnya, karena guru yang langsung bersinggungan dengan peserta didik, untuk memberikan bimbingan yang muaranya akan menghasilkan tamatan yang diharapkan. Untuk itu kinerja guru harus selalu ditingkatkan. Upaya-upaya untuk meningkatkan kinerja itu biasanya dilakukan dengan cara memberikan motivasi, mengadakan supervisi, memberikan insentif, memberikan kesempatan yang baik untuk berkembang dalam karir, meningkatkan kemampuan, gaya kepemimpinan yang baik dan upaya-upaya lainnya yang relevan. Sementara kinerja guru dapat ditingkatkan apabila yang bersangkutan mengetahui apa yang diharapkan dan kapan bisa menetapkan harapan-harapan yang diakui hasil kerjanya (Rachman, 2016).

Dalam upaya meningkatkan kinerja guru baik dalam hal kompetensi maupun keterampilan dalam proses pembelajaran, sekolah perlu memperhatikan faktor-faktor yang dapat meningkatkan kinerja guru tersebut dalam mengembangkan segala potensinya. Salah satunya yaitu dengan mengikuti pendidikan dan pelatihan (Musfah, 2011). This competence for teachers is able to foster motivation in carrying out their duties, but this does not happen in the field. Because there are still frequent findings that teachers have not carried out their duties with a full sense of responsibility and professionalism (Suratman, 2020). Kinerja orang dalam pekerjaannya akan meningkat akibat pelatihan peningkatan guru. Pendidikan dan pelatihan memberi kesempatan kepada guru untuk mendapatkan pengetahuan, keterampilan, sikap baru yang mengubah perilakunya yang pada akhirnya akan meningkatkan kinerja serta akan berdampak pula pada peningkatan prestasi belajar siswa.

The effort to improve teacher's professionalism certainly needs a number of things, including schoolbased management that must be improved and implemented according to the rules, teacher's professionalism must be improved by giving directives from school principals, supervisors so that the effort itself teacher's performance goals can be achieved as expected. Teachers must also be provided with provisions to deliver learning material to students, for example given training and education supplies, workshops, seminar workshops, so that teachers can find out about the development of the education world as needed (Rohma, 2020).

Melalui diklat pengetahuan guru akan semakin bertambah dan dapat diterapkan kepada peserta didik dalam proses pembelajaran. Jika para guru tersebut menjalankan prinsip-prinsip profesionalisme dalam menjalankan tugas dan fungsinya akan menghasilkan kinerja yang baik. Keberhasilan guru dalam proses pembelajaran sangat ditentukan oleh kinerja guru sebagai pendidik. Kinerja guru merupakan kemampuan seorang guru dalam melaksanakan tugas pembelajaran di sekolah dan bertanggung jawab atas peserta didik di bawah bimbingannya dengan meningkatkan prestasi belajar peserta didik. Kinerja guru dalam pembelajaran menjadi bagian terpenting dalam mendukung terciptanya proses pembelajaran secara efektif (Widodo, 2015).

Guru wajib memiliki kualifikasi akademik, sertifikasi pendidik, kompetensi, sehat jasmani dan rohani, serta memiliki kemampuan untuk mewujudkan tujuan pendidikan nasional. Kompetensi guru merupakan kemampuan dari seorang guru dalam melaksanakan kewajiban-kewajibannya secara bertanggung jawab dan layak (Fitria, 2019). Kinerja guru atau prestasi kerja merupakan hasil yang dicapai oleh guru dalam melaksanakan tugas-tugas yang dibebankan kepadanya yang didasarkan atas kecakapan, pengalaman dan kesungguhan serta penggunaan waktu. Kinerja guru akan baik jika guru telah melaksanakan unsur-unsur yang terdiri kesetiaan dan komitmen yang tinggi pada tugas mengajar, menguasai dan mengembangkan bahan pelajaran, kedisiplinan dalam mengajar dan tugas lainnya, kreativitas dalam pelaksanaan pengajaran, kerjasama dengan semua warga sekolah, kepemimpinan yang menjadi panutan siswa, kepribadian yang baik, jujur dan obyektif dalam membimbing siswa, serta tanggungjawab terhadap tugasnya (Buchori, 2015).

Dalam melaksanakan tugasnya, guru tidak berada dalam lingkungan yang kosong. la bagian dari dari sebuah "mesin besar" pendidikan nasional, dan karena itu ia terikat pada rambu-rambu yang telah ditetapkan secara nasional mengenai apa yang mesti dilakukannya. Hal seperti biasa dimanapun, namun dalam konteks 
profesionalisme guru dimana mengajar dianggap sebagai pekerjaan profesional, maka guru dituntut untuk profesional dalam melaksanakan tugasnya (Sani, 2017).

Pada dasarnya terdapat seperangkat tugas yang harus dilaksanakan oleh guru terkait dengan profesinya sebagai pengajar, yakni (1) tugas dalam bidang profesi meliputi mendidik, mengajar dan melatih peserta didik; (2) tugas dalam bidang kemanusiaan meliputi bahwa guru di sekolah harus dapat menjadi orang tua kedua, dapat memahami peserta didik, membantu peserta didik dalam mentransformasikan dan mengidentifikasikan diri peserta itu sendiri; (3) tugas dalam bidang kemasyarakatan meliputi membantu masyarakat untuk dapat memperoleh ilmu pengetahuan dan mencerdaskan bangsa Indonesia seutuhnya berdasarkan Pancasila (Uno, 2012).

Menurut Mangkunegara (2011) dalam jurnal penelitiannya menjelaskan bahwa kinerja guru merupakan proses pembelajaran sebagai upaya mengembangkan kegiatan yang ada menjadi kegiatan yang lebih baik, sehingga tujuan pendidikan yang telah ditetapkan dicapai dengan baik melalui suatu kegiatan pembelajaran yang dilaksanakan oleh guru sesuai dengan target dan tujuan. Selanjutnya Rusyan (2016) mengemukakan bahwa kinerja guru adalah melaksanakan proses pembelajaran baik dilakukan di dalam kelas maupun di luar kelas di samping mengerjakan kegiatan-kegiatan lainnya, seperti mengerjakan administrasi sekolah dan administrasi pembelajaran, melaksanakan bimbingan dan layanan pada para siswa, serta melaksanakan penilaian.

Kinerja guru dipengaruhi oleh dua faktor, yaitu: faktor kemampuan dan faktor motivasi (Soekarno, 2009). Motivasi merupakan daya penggerak dari dalam dan di dalam subjek untuk melakukan aktivitasaktivitas tertentu demi mencapai suatu tujuan (Sardiman, 2013), bila motivasi kerjanya tinggi maka akan berpengaruh pada kinerja yang tinggi dan sebaliknya jika motivasinya rendah maka akan menyebabkan kinerja yang dimiliki tersebut rendah.

Berdasarkan data awal penelitian yang peneliti lakukan di SD Negeri 1 Sungai Lilin, SD Negeri 2 Sungai Lilin dan SD Negeri 1 Pinang Banjar, diperoleh keterangan bahwa sebagian guru sudah menunjukkan kinerja yang baik dalam menjalankan tugas dan fungsinya. Akan tetapi, masih ada sebagian kinerja guru yang rendah antara lain: mengajar secara monoton tanpa adanya inovasi pembelajaran, masih ada guru yang terlambat masuk kelas dan keluar kelas sebelum jadwal pergantian jam pelajaran. Selain itu, ada pula guru yang tanpa adanya persiapan yang matang dan kurangnya penguasaan terhadap materi ajar sehingga hanya sekedar menyampaikan materi. Maka peneliti berpandangan bahwa ada hal yang menjadi faktor sehingga terjadi hal yang seperti itu. Untuk dapat meningkatkan kinerja guru tersebut maka sangat penting untuk mengikuti pendidikan dan pelatihan guru, agar proses pembelajaran yang diberikan berjalan dengan baik. Disamping itu juga, perlu adanya pemanfaatan sarana prasarana sekolah, sehingga siswa dapat belajar dengan baik maupun saat menyampaikan materi pembelajaran dengan menggunakan teknik pembelajarran aktif, inovatif, kreatif, efektif dan menyenangkan. Berdasarkan kerangka latar belakang di atas, peneliti ingin mengkaji lebih lanjut melalui penelitian yang berjudul, Pengaruh budaya sekolah dan diklat terhadap kinerja guru di SD Negeri di Kecamatan Sungai Lilin..

\section{METODE PENELITIAN}

Menurut Sukmadinata (2015), metode penelitian merupakan rangkaian cara atau kegiatan pelaksanaan penelitian yang didasari oleh asumsi-asumsi dasar, pandangan-pandangan filosofis dan ideologis, pertanyaan dan isu-isu yang dihadapi. Metode penelitian memiliki rancangan penelitian tertentu.

Metode penelitian ini adalah penelitian kuantitatif dengan mendeskripsikan hasil temuan penelitian. Penelitian kuantitatif didasari oleh filsafat positivisme yang menekankan fenomena-fenomena objektif dan dikaji secara kuantitatif. Populasi dalam penelitian ini adalah SD Negeri 1 Sungai Lilin, SD Negeri 2 Sungai Lilin, SD Negeri 1 Kinang Banjar, dengan pengambilan sampel dalam penelitian ini menggunakan purposive sampling, yaitu guru yang dijadikan sampel penelitian adalah guru-guru PNS di masing-masing sekolah dasar dengan jumlah sebanyak 44 orang guru PNS.

Dalam pengumpulan data dibutuhkan teknik, baik teknik dalam penyediaan data, maupun teknik dalam melakukan klasifikasi data yang telah dikumpulkan. Hal senada juga dikemukakan Sugiyono (2015) bahwa metode pengumpulan data adalah cara yang dilakukan untuk mengumpulkan data, sedangkan teknik pengumpulan data adalah cara yang ditempuh dalam menjalankan metode yang telah dipilih dimana menggunakan data angket dan dokumentasi. Teknik analisis data dalam penelitian ini menggunakan teknik analisis data korelasi sederhana dan regresi berganda dengan bantuan program SPSS For Windows Versi 21. Adapun tahap pelaksanaan analisis meliputi: (1) analisis deskriptif, (2) uji persyaratan analisis, dan (3) uji hipotesis.

\section{HASIL DAN PEMBAHASAN}

\section{Pengujian Hipotesis Parsial Variabel Budaya Sekolah (X1) terhadap Kinerja Guru (Y)}

Dari hasil penelitian menunjukan bahwa antara budaya sekolah memberikan pengaruh yang kurang kuat terhadap kinerja guru SD Negeri di Kecamatan Sungai Lilin. Berdasarkan tabel 1 dan 2 didapat angka 
koefisien konstanta (Constant) $=4,233$ dan angka koefisien $X 1=0,305$, sehingga diperoleh persamaan regresi linear sederhana $\hat{Y}=4,233+0,305 X 1$ atau persamaan regresi secara parsial antara variabel $X 1$ terhadap $Y$ adalah $Y=4,233+0,305 X 1$. selanjutnya persamaan tersebut digunakan untuk menjelaskan pengaruh budaya sekolah (X1) terhadap kinerja guru SD Negeri di Kecamatan Sungai Lilin (Y). Hasil analisis koefisien diperoleh thitung sebesar 2,079. kriteria uji hipotesis jika thitung $>\mathrm{t}$ tabel maka Ha diterima sedangkan jika thitung $<\mathrm{t}$ tabel maka Ha ditolak dan untuk menentukan ttabel dicari pada $a=5 \%: 2=2,5 \%$ (uji 2 sisi) dengan derajat kebebasan $(\mathrm{df})=\mathrm{n}-\mathrm{k}$ atau $\mathrm{df}=44-2=42$ ( $\mathrm{n}$ adalah jumlah sampel dan $\mathrm{k}$ adalah jumlah variabel independet). Dengan pengujian dua sisi (signifikan $=0,025$ ) hasil diperoleh untuk $t$ tabel sebesar 2,079. berdasarkan penjelasan di atas yaitu thitung $=2,079$ dan ttabel $=2,019$, maka thitung $>$ ttabel yang berarti Ho ditolak dan Ha diterima. Dengan demikian dapat dikatakan bahwa secara parsial ada pengaruh positif dan signifikan antara budaya sekolah terhadap kinerja guru SD Negeri di Kecamatan Sungai Lilin. Analisis koesifien determinasi digunakan untuk mengetahui presentasi sumbangan pengaruh variabel independen terhadap variabel dependen. Berdasarkan tabel di atas, dapat dijelaskan angka yang diperoleh koefisien determinasi $R$ Square (R2) sebesar 0,072 yang berarti bahwa budaya sekolah (X1) mampu mempengaruhi kinerja guru SD Negeri di Kecamatan Sungai Lilin (Y) dengan memberikan kontribusi sebesar 7,2\%.

Tabel 1. Hasil Koefisien Analisis Regresi Linear Sederhana secara Parsial Variabel Budaya Sekolah $\left(\mathrm{X}_{1}\right)$ terhadap Coefficients $^{\mathrm{a}}$ Kinerja Guru $(\mathrm{Y})$

\begin{tabular}{|l|l|l|l|l|l|}
\hline \multirow{2}{*}{ Model } & \multicolumn{2}{l|l|}{ Unstandardized Coefficients } & $\begin{array}{l}\text { Standardized } \\
\text { Coefficients }\end{array}$ & Sig. \\
\cline { 2 - 4 } & $\mathrm{B}$ & Std. Error & Beta & & \\
\hline (Constant) & 4.233 & .418 & & 10.125 & .000 \\
Budaya Sekolah & .248 & .119 & .305 & 2.079 & .044 \\
\hline
\end{tabular}

a. Dependent Variable: Kinerja Guru

Tabel 2. Hasil Analisis Koefisien Determinasi Variabel Budaya Sekolah $\left(\mathrm{X}_{1}\right)$ terhadap Kinerja Guru $(\mathrm{Y})$ Model Summaryb

\begin{tabular}{|l|l|l|l|l|}
\hline Model & R & R Square & Adjusted R Square & $\begin{array}{l}\text { Std. Error of the } \\
\text { Estimate }\end{array}$ \\
\hline 1 & $305 a$ & 093 & .072 & .28470 \\
\hline
\end{tabular}

a. Predictors: (Constant), Budaya Sekolah

\section{Pengujian Hipotesis Parsial Variabel Diklat (X2) terhadap Variabel Kinerja Guru (Y)}

Dari hasil penelitian pada tabel 3 dan 4 menunjukan bahwa Terdapat pengaruh yang positif dan signifikan antara diklat (X2) terhadap kinerja guru SD Negeri di Kecamatan Sungai Lilin (Y). Berdasarkan tabel 3 dan 4 di dapat angka koefisien konstanta (Constant) $=2,173$ dan angka koefisien $X 2=0,332$, sehingga diperoleh persamaan regresi linear sederhana $\hat{Y}=2,173+0,332 X$ atau persamaan regresi secara parsial antara variabel $X 2$ terhadap $Y$ adalah $Y=2,173+0,332 X 2$. selanjutnya persamaan tersebut digunakan untuk menjelaskan pengaruh diklat (X1) terhadap kinerja guru SD Negeri di Kecamatan Sungai Lilin (Y).

Tabel 3. Hasil Koefisien Regresi Linear Sederhana secara Parsial Variabel Diklat ( $\left.\mathrm{X}_{2}\right)$ terhadap Kinerja Guru (Y) Coefficientsa

\begin{tabular}{|c|c|c|c|c|c|c|}
\hline \multirow{2}{*}{\multicolumn{2}{|c|}{ Model }} & \multicolumn{2}{|c|}{ Unstandardized Coefficients } & Standardized & \multirow[t]{2}{*}{$\mathrm{t}$} & \multirow[t]{2}{*}{ Sig. } \\
\hline & & $\bar{B}$ & Std. Error & Beta & & \\
\hline & (Constant) & 2.173 & .526 & & 4.129 & .000 \\
\hline & Diklat & .336 & .148 & .332 & 2.278 & .028 \\
\hline
\end{tabular}

a. Dependent Variable: Kinerja Guru

Tabel 4. Hasil Analisis Koefisien Determinasi Variabel Diklat $\left(\mathrm{X}_{2}\right)$ terhadap Kinerja Guru (Y) Model Summary

\begin{tabular}{|c|c|c|c|c|}
\hline Model & $\mathrm{R}$ & $\mathrm{R}$ Square & Adjusted R Square & $\begin{array}{c}\text { Std. Error of the } \\
\text { Estimate }\end{array}$ \\
\hline 1 & $.332 \mathrm{a}$ & .110 & .089 & .28207 \\
\hline
\end{tabular}

a. Predictors: (Constant), Diklat 
Hasil analisis koefisien diperoleh thitung sebesar 2,278 kriteria uji hipotesis jika thitung $>\mathrm{t}$ tabel maka Ha diterima sedangkan jika thitung < ttabel maka Ha ditolak dan untuk menentukan ttabel dicari pada $a=5 \%: 2=2,5 \%$ (uji 2 sisi) dengan derajat kebebasan (df) =n-k atau df $=44-2=42$ ( $n$ adalah jumlah sampel dan $\mathrm{k}$ adalah jumlah variabel independet). Dengan pengujian dua sisi (signifikan $=0,025$ ) hasil diperoleh untuk ttabel sebesar 2,019. berdasarkan penjelasan di atas yaitu thitung $=2,278$ dan ttabel = 2,019, maka thitung > ttabel yang berarti Ho ditolak dan Ha diterima. Dengan demikian dapat dikatakan bahwa secara parsial ada pengaruh positif dan signifikan antara kompetensi sosial guru terhadap hasil belajar siswa.

Hasil analisis regresi linear sederhana berdasarkan output Model Summary diperoleh angka R sebesar 0,332 berarti hubungan antara kedua variabel $X 2$ terhadap $Y$ yang menunjukkan kategori pengaruh yaitu kurang kuat. Karena nilai korelasi ganda berada di antara 0,200 - 0,399. dengan demikian dapat dikatakan bahwa antara diklat memberikan pengaruh yang kurang kuat terhadap kinerja guru SD Negeri di Kecamatan Sungai Lilin. Analisis koesifien determinasi digunakan untuk mengetahui presentasi sumbangan pengaruh variabel independen terhadap variabel dependen. Berdasarkan tabel di atas, dapat dijelaskan angka yang diperoleh koefisien determinasi R Square (R2) sebesar 0,110 yang berarti bahwa diklat (X2) mampu mempengaruhi kinerja guru SD Negeri di Kecamatan Sungai Lilin (Y) dengan memberikan kontribusi sebesar $11 \%$.

\section{Pengujian Hipotesis Simultan Variabel X1 dan X2 ke Y}

Dari hasil penelitian memperlihatkan terdapat pengaruh yang positif dan signifikan antara Budaya Sekolah (X1) dan Diklat (X2) secara simultan terhadap hasil belajar siswa (Y).

Tabel 5. Hasil Analisis Regresi Linear Berganda Simultan (Uji-F)

ANOVA
\begin{tabular}{|ll|l|l|l|l|l|}
\hline Model & & Sum of Squares & df & Mean Square & F & Sig. \\
\hline \multirow{2}{*}{1} & Regression & .873 & 2 & .436 & 6.207 & $.004 \mathrm{~b}$ \\
& Residual & 2.882 & 41 & .070 & & \\
& Total & 3.755 & 43 & & & \\
\hline
\end{tabular}

a. Dependent Variable: Kinerja Guru

b. Predictors: (Constant), Budaya Sekolah, Diklat

Tabel 6. Hasil Analisis Koefisien Regresi Linear Berganda Variabel Budaya Sekolah ( $\mathrm{X}_{1}$ ) dan Diklat $\left(\mathrm{X}_{2)}\right.$ secara Simultan terhadap Kinerja Guru (Y)

Coefficients $^{a}$

\begin{tabular}{|l|l|l|l|l|l|}
\hline \multirow{2}{*}{ Model } & \multicolumn{2}{l|l|l|}{ Unstandardized Coefficients } & $\begin{array}{l}\text { Standardized } \\
\text { Coefficients }\end{array}$ & Sig. \\
\cline { 2 - 4 } & $\mathrm{B}$ & Std. Error & Beta & & \\
\hline (Constant) & 3.012 & .594 & & 5.074 & .000 \\
Budaya Sekolah & .287 & .112 & .353 & -2.557 & .014 \\
Diklat & .381 & .140 & .376 & 2.726 & .009 \\
\hline
\end{tabular}

a. Dependent Variable: Kinerja Guru

Tabel 7. Hasil Analisis Koefisien Determinasi Variabel $X_{1}$ dan $X_{2}$ secara Simultan tehadap $Y$ Model Summary

\begin{tabular}{|c|c|c|c|c|}
\hline Model & $\mathrm{R}$ & Square & Square & $\begin{array}{l}\text { Std. Error of } \\
\text { the Estimate }\end{array}$ \\
\hline 1 & $.482^{a}$ & .232 & .195 & .26513 \\
\hline
\end{tabular}

a. Predictors: (Constant), Diklat, Budaya Sekolah

b. Dependent Variable: Kinerja Guru

Berdasarkan Fhitung pada tabel 5, 6 dan 7, diketahui bahwa nilai yang diperoleh 6,207. Kriteria uji hipotesis jika Fhitung > Ftabel maka Ha diterima, dan jika sebaliknya Fhitung > Ftabel, maka Ha ditolak. Berdasarkan Ftabel pada taraf nyata ? $(0,05)$ dengan db pembilang 2 (ditentukan dari banyaknya variabel bebas dan db penyebut 41 (ditentukan dari banyak sampel dikurang variabel bebas dikurang satu) atau dapat ditentukan melalui aplikasi program Excell pada sel kosong ketik rumus = FINV $(0,05,2,41)$ diperoleh angka sebesar 3,231 (Prayitno, 2010:116). Berdasarkan penjelasan di atas diketahui F $\neg$ hitung = 6,207 dan Ftabel 3,231 dimana Fhitung > Ftabel yang berarti Ha diterima atau dapat dikatakan ada pengaruh positif yang signifikan antara budaya sekolah dan diklat terhadap kinerja guru SD Negeri di Kecamatan Sungai Lilin. 
Berdasarkan tabel di atas, di dapat angka koefisien konstanta (Constant) $=3,012$ dan angka koefisien $X 1=0,353$ dan angka koefisien $X 2=0376$, sehingga diperoleh persamaan regresi linear berganda $Y=3,012+$ $0,353 \times 1+0,376 \times 2$. selanjutnya persamaan tersebut digunakan untuk menjelaskan pengaruh budaya sekolah (X1) dan diklat (X2) terhadap kinerja guru SD Negeri di Kecamatan Sungai Lilin (Y). Nilai koefisien variabel $X 1=0,353$ dan $X 2=0,376$ bernilai positif, maka nilai variabel $Y$ selalu mengalami kenaikan artinya jika semakin tinggi tingkat budaya sekolah $(X \neg 1 \neg$ dan diklat $(X \neg 2)$ maka semakin tinggi pengaruhnya terhadap kinerja guru SD Negeri di Kecamatan Sungai Lilin (Y).

Hasil analisis regresi linear berganda berdasarkan output Model Summary diperoleh angka R sebesar 0,482 berarti hubungan antara variabel $X 1$ dan $X 2$ (independent) terhadap $Y$ (dependent) yang menunjukkan kategori pengaruh yaitu cukup kuat. Karena nilai korelasi ganda berada di antara 0,400 - 0,599. dengan demikian dapat dikatakan bahwa antara budaya sekolah dan diklat memberikan pengaruh yang cukup kuat terhadap kinerja guru SD Negeri di Kecamatan Sungai Lilin. Angka yang diperoleh koefisien determinasi R Square (R2) sebesar 0,232 yang berarti bahwa budaya sekolah (X1) dan diklat (X2) mampu mempengaruhi kinerja guru SD Negeri di Kecamatan Sungai Lilin (Y) dengan memberikan kontribusi sebesar 23,2\%, sedangkan 76,8\% dijelaskan oleh faktor-faktor yang tidak termasuk dalam penelitian ini

\section{SIMPULAN}

ada pengaruh yang signifikan budaya sekolah terhadap kinerja guru di SD Negeri Kecamatan Sungai Lilin; 2) ada pengaruh yang signifikan diklat terhadap kinerja guru di SD Negeri Kecamatan Sungai Lilin; 3) ada pengaruh yang signifikan budaya sekolah dan diklat secara bersama-sama terhadap kinerja guru di SD Negeri Kecamatan Sungai Lilin; 4) kontribusi sumbangan pengaruh antar variabel diketahui bahwa pengaruh budaya sekolah terhadap kinerja guru di SD Negeri Kecamatan Sungai Lilin memberikan sumbangan pengaruh sebesar 7,2\%; 5) kontribusi sumbangan pengaruh diklat terhadap kinerja guru di SD Negeri Kecamatan Sungai Lilin memberikan sumbangan pengaruh sebesar $11 \%$; 6) kontribusi pengaruh budaya sekolah dan diklat secara bersama-sama terhadap kinerja guru di SD Negeri Kecamatan Sungai Lilin memberikan sumbangan pengaruh sebesar $23,2 \%$. Sedangkan sisanya $76,8 \%$ dipengaruhi oleh faktor lain yang tidak tercantum di dalam penelitian ini.

\section{UCAPAN TERIMA KASIH}

Ucapan terima kasih diberikan kepada Kepala SD Negeri 1 Sungai Lilin, Rektor Universitas PGRI Palembang, Direktur Pascasarjana Universitas PGRI Palembang dan Ketua Program Studi Magister Manajemen Pendidikan Universitas PGRI Palembang yang telah membantu dalam penyelesaian jurnal ini. Kemudian terima kasih juga kepada teman-teman mahasiswa Pascasarjana Universitas PGRI Palembang dan semua pihak yang telah membantu penulisan dan penerbitan jurnal ini.

\section{DAFTAR PUSTAKA}

Asvio, N., Yamin, M., \& Risnita. (2019). Influence of Leadership Style, Emotional Intelligence and Job Satisfaction toward Organizational Commitment (Survey at SMA Muhammadiyah South Sumatera). International Journal of Scientific \& Technology Research 8 (8).

Buchori, A. (2015). Kinerja Guru. Jakarta: Raja Graffindo Persada.

Fathurrohman, M. (2012). Belajar dan Pembelajaran Meningkatkan Mutu Pembelajaran Sesuai Standar Nasional. Jakarta: Pustaka Pelajar.

Fitria, H., Kristiawan, M., \& Rahmat, N. (2019). Upaya Meningkatkan Kompetensi Guru Melalui Pelatihan Penelitian Tindakan Kelas. Abdimas Unwahas, Vo. 4, No. 1.

Halim. (2014). Etika Profesi Guru. Jakarta: Kata Pena.

Hamalik, O. (2012). Motivasi Belajar-Mengajar. Jakarta: Raja Graffindo Persada.

Hamalik, O. (2014). Implementasi Guru dalam Proses Belajar-Mengajar. Jakarta: Raja Graffindo Persada.

Hendarman dan Rohanim. (2018). Kepala Sekolah Sebagai Manajer Teori dan Praktik. Bandung: Remaja Rosdakarya.

Mangkunegara. (2011). Jurnal: Kinerja Guru dan Upaya Meningkatkannya. Jakarta: www.emaskuwinggomangkunegara.html. (Diakses pada 20 November 2019).

Mulyasa. (2012). Manajemen Dan Kepemimpinan Kepala Sekolah. Jakarta: Bumi Aksara.

Musfah. (2011). Pendidikan dan Pelatihan Bagi Guru. Jakarta: Rajawali Pers.

Poerwadarminta. (2015). Motivasi Belajar. Jakarta: Erlangga.

Rachman. (2016). Guru Powerfull (Kunci Sukses Menjadi Guru Efektif). Bandung: Kolbu. 
Rohma, S., Harapan, E., \& Wardiah, D. (2020). The Influence of School-Based Management and Teacher's Professionalism toward Teacher's Performance. Journal of Social Work and Science Education, 1(1), 13-23. Retrieved from https://ejournal.karinosseff.org/index.php/jswse/article/view/6

Rusyan. (2016). Manajemen Peningkatan Kinerja Guru. Konsep Strategi dan Implementasi. Bandung: Remaja Rosdakarya.

Sani, B. (2017). Kompetensi Pedagogik, Teori dan Praktik Untuk Peningkatan Kinerja dan Kualitas Guru. Jakarta: Kata Pena.

Sardiman. (2013). Interaksi dan Motivasi Belajar Mengajar. Jakarta: Raja Grafindo Persada.

Soekarno, P. R. (2009). Kinerja Guru dan Faktor-Faktor yang Mempengaruhinya. http://cindoprameswari.com/2009/02/kinerja-guru-dan-faktor-faktor-yangmempengaruhinya.html (20 November 2019).

Sugiyono. (2010). Metode Penelitian Pendidikan Pendekatan Kuantitatif, Kualitatif dan R\&D. Bandung: Alfabeta.

Sugiyono. (2015). Metode Penelitian Pendidikan, Pendekatan Kuantitatif, Kualitatif dan R \& D. Bandung: Alfabeta.

Sukmadinata, N. S. (2015). Metode Penelitian Pendidikan. Bandung: Remaja Rosdakarya.

Sukmadinata. (2016). Pengendalian Mutu Pendidikan Sekolah Menengah, Konsep Prinsip dan Instrumen. Bandung: Refika Aditama.

Suratman, S., Arafat, Y., \& Eddy, S. (2020). The Influence of Principal's Leadership and Teacher's Competence toward Teacher's Performance in Indonesia. Journal of Social Work and Science Education, 1(2), 96104. Retrieved from https://ejournal.karinosseff.org/index.php/jswse/article/view/32

Tobari., Kristiawan, M., \& Asvio, N. (2018). The Strategy of Headmaster on Upgrading Educational Quality in Asean Economic Community (AEC) Era. International Journal of Scientific \& Technology Research 7 (4).

Uno, H. B. (2012). Profesi Kependidikan. Jakarta: Bumi Aksara.

Widodo, S. E. (2015). Manajemen Pengembangan Sumber Daya Manusia. Yogyakarta: Pustaka Pelajar. Yamin, M. (2015). Manajemen Pembelajaran Kelas. Jakarta: Gaung Persada.

Zamroni. (2011). Pendidikan Demokrasi pada Masyarakat Multikultural. Yogyakarta: Penerbit Ombak. 